\title{
Civilian casualties and public support for military action: Experimental evidence
}

\author{
(forthcoming, Journal of Conflict Resolution) \\ Robert Johns* \\ University of Essex
}

and

\author{
Graeme A. M. Davies \\ University of Leeds
}

* Corresponding author

Department of Government, University of Essex, Wivenhoe Park, Colchester CO4 3SQ, U.K.

E-mail: rajohn@essex.ac.uk

In contrast to the expansive literature on military casualties and support for war, we know very little about public reactions to foreign civilian casualties. This article, based on representative sample surveys in the US and Britain, reports four survey experiments weaving information about civilian casualties into vignettes about Western military action. These produce consistent evidence of civilian casualty aversion: where death tolls were higher, support for force was invariably and significantly lower. Casualty effects were moderate in size but robust across our two cases and across different scenarios. They were also strikingly resistant to moderation by other factors manipulated in the experiments, such as the framing of casualties or their religious affiliation. The importance of numbers over even strongly humanizing frames points towards a cost-benefit rather than a social-psychological model of casualty aversion. Either way, civilian casualties deserve a more prominent place in the literature on public support for war.

\section{Acknowledgements}

The data analyzed here come from two sources: a Time-sharing Experiments in the Social Sciences (TESS) survey (Project \#730); and surveys funded by the Economic and Social Research Council (RES-062-23-1952) as part of a project to investigate 'Foreign policy attitudes and support for war among the British public'. We gratefully acknowledge the support from both funders, and the guidance we received from colleagues in designing the surveys. The research in this article has been presented at the 2012 Annual Convention of the International Studies Association and at seminars at Nuffield College, the University of Essex and the University of Lancaster. In all cases, we thank participants for comments and suggestions. 
At the height of the conflicts in Afghanistan and Iraq, civilians risked being the forgotten casualties. They received much less attention from the same American media which give extensive and sympathetic coverage to the deaths, repatriation and funerals of military casualties (Althaus et al., 2014). They were downplayed by the same British leaders who solemnly read out tributes to fallen service personnel in Parliament. And military strategists in both countries favored a doctrine of air strikes which, despite advances in precision munitions, still risks foreign civilian lives in significant numbers in order to minimize the risks to their own troops.

In more recent years, however, civilian casualties have begun to receive more attention. This is partly due to the strategic choice mentioned above: with action increasingly taken via unmanned drones, military casualties have become much rarer while civilian death tolls continue to mount. The need to protect civilians has also become central to the case for military action in a context like Syria (e.g. Landay et al., 2015; Wright, 2015), even if the risks to US and British military remain equally central to the case against intervention.

Given the earlier imbalance, it is not surprising that civilian casualties were largely overlooked in research - much of it triggered by Iraq and Afghanistan - on the drivers of public support for war. Since military casualties were more conspicuous in public debate, it made sense that they would have a greater influence on citizens' reactions, and in turn that researchers would focus on military casualty aversion. Now that civilian casualties are becoming more prominent in media coverage of conflict, however, a question arises about public reactions. Would we expect reporting of foreign civilian deaths to have a dampening effect on public support for military action? Or did media and academic focus on military casualties reflect the public's own preoccupation with its own servicemen and women over foreign civilians? Answering this question would make both an empirical and a normative contribution. It would improve our understanding of the conditions under which citizens are prepared to support military action. It would also tell us whether support for force is systematically higher than it would be if civilian deaths become a more central presence in elite discussion and media coverage of military action. 
The scant existing evidence makes it hard to assess the strength of public reactions to civilian casualties. When prompted in opinion polls, respondents express considerable concern (e.g. Pew Research 2013). But such disquiet is easy to express yet, according to Mueller (2000), has not translated into public opposition to policies that result in mass casualties. More generally, civilian casualty aversion has not been treated to anything like the detailed methodological attention - a combination of experimental evidence along with time series analyses of casualty rates and poll trends - paid to military casualty aversion.

In this article, we report on a series of survey experiments - two fielded in parallel in the US and in Britain, two fielded only in the latter - in which information about civilian casualties is woven into vignettes about Western military action. The experimental approach has the merit of providing the casualty information that is often missing from public discourse, but in a much less obtrusive way than is achieved by survey questions that prime concern for civilians. Having considered reasons why the public might - and might not - be averse to civilian casualties, and assessed likely moderators of public concern, we then describe the data sources and present results from the four experiments in turn. We find clear and consistent evidence of civilian casualty aversion in both publics, an aversion that is driven strongly by casualty numbers and surprisingly weakly by framing effects and other characteristics of the civilians at risk.

\section{The possibility of civilian casualty aversion}

Departing from Mueller's (1973) famous study using cumulative casualty tolls to predict trends in American public approval of the Korean and Vietnam wars, a major literature has built up on the relationship between military casualties and public support for military action (e.g. Larson 1996; Gartner and Segura 1998; Gelpi et al. 2006, 2009; Boettcher and Cobb 2006; Gartner 2008a; Kriner and Shen 2013). The works just cited represent only a fraction of that research, and there is no space to review it in detail here. Instead we just want to highlight one feature of it: these studies are concerned solely with only one of the types of casualties risked by the use of 
force. We now know a great deal about how the mass public - at least, the US public - reacts to its own military casualties. We know very little about whether and how the public reacts to foreign civilian casualties. ${ }^{1}$ The focus is so established that the term 'casualties' is typically used without any prior qualifier to denote military deaths.

Before assessing the handful of exceptions, we should first acknowledge that the general preoccupation with military casualties is to some extent understandable. Military deaths do tend to receive more attention than do civilian deaths in political debate and media coverage. To the extent that mass opinion is basically an 'echo chamber' (Key 1966), we would expect the public to be more responsive to the former. However, that is not to say that civilian casualties are ignored. From an analysis of press reporting of the Iraq War, Larson and Savych report that "the topic of civilian casualties received a small amount of reporting through the fall of 2002, became much more prominent once the war actually was under way in March 2003, and, with the conclusion of major combat operations on May 1, dropped back to pre-war levels" $(2006,164)$. The Center for Media and Public Affairs (2003a, 2003b) conducted a parallel analysis of TV news and found that, during the major combat phase, $15-25 \%$ of war stories mentioned civilian casualties. Finally, and with a view to explicit comparison of the reporting of military and civilian casualties, we conducted our own content analysis of reporting by the New York Times and Washington Post throughout the Iraq War and subsequent occupation (2003-2011). The results, set out in online appendix A1, show two main things. First, while civilian casualties were indeed mentioned less often than military casualties in news stories during that period, the gap was never huge and narrowed over time, even reversing by the final year of our analysis.

\footnotetext{
${ }^{1}$ Consider the 2009 book by Christopher Gelpi and co-authors, Paying the Human Costs of War. Just five of its 263 pages are concerned with the civilian human costs. Yet Gelpi et al. deserve praise rather than criticism because those five pages represent one of the few assessments to date of mass public reactions to civilian casualties $(2009,255-60)$.
} 
Second, the bigger military-civilian difference lies not in the frequency but in the content of mentions: civilian death reports are less detailed and the number of deaths is often disputed or omitted altogether. Overall, then, it is arguable that the academic neglect of civilian casualties undersells their role in public discourse. They are reported less often than military casualties, and reported differently, but reported enough to make it worth investigating their effect on public support for military action.

Of course, even if military and civilian casualties were equally prominent in elite discourse, there remain several reasons to expect the public to be more tolerant of the latter. Some may simply reject a distinction between combatants and non-combatants and regard civilian casualties as another example of killing the enemy. Another normative justification could be via reciprocity, citizens reasoning that "they would do the same to us" - or, indeed, that "they have already done the same to us" (Brandt et al. 2008). Third, insofar as the public recognizes the trade-off faced by military strategists between maintaining soldier safety and averting civilian casualties (Shaw 2002; Downes 2006), and wishes to minimize the risks to its own troops, civilian deaths may be regarded as a necessary evil.

The two remaining reasons are particularly relevant to our own empirical work. One derives from the 'foreign-ness' of civilian casualties, which in turn contributes to their outgroup status (Rothbart and Korostelina 2006). Of the many studies of hostility against outgroups, some have highlighted infrahumanization - an implicit tendency to regard the outgroup as lacking some essentially human characteristics (Castano and Giner-Sorolla 2006; Haslam et al. 2008) as a mechanism by which the public might play down the cost and significance of civilian casualties. A final reason for expecting limited public responsiveness to civilian casualties is the phenomenon of proportional numbing, whereby people become "less sensitive to losses of life when those statistical losses are construed as small fractions of larger reference groups of at-risk individuals" (Friedrich and Dood 2009, 2542). Slovic (2007) argues that this feature of reasoning has left publics 'numbly indifferent' even to mass genocides. Since the population of foreign 
civilians dwarfs that of military personnel, we can again expect the public to react more sensitively to the latter type of casualties.

The key point about most of these reasons is that they explain a relative insensitivity to civilian casualties. Any absolute assumption - that the public is entirely insensitive to civilian deaths rather than simply less sensitive to them - is much stronger and more questionable. There are several theoretical reasons to suppose that the domestic public will be at least somewhat responsive to foreign civilian casualties. Once more, some of these are straightforwardly normative. Citizens may simply apply the same principle - that non-combatants are innocent bystanders and so military action that endangers them in large numbers cannot be justified - that increasingly drives international law (Shaw 2002; Bohrer and Osiel 2013). There may again be a reciprocity argument, too: "how would we like it if they attacked our civilians rather than our trained and armed forces?" Then there is the fact that outgroups can be humanized just as they can be infrahumanized. A newspaper story about a bride being among the civilians killed at a wedding (see Wafa and Burns 2008), facilitates the sympathy that is a main driver of casualty aversion. Finally, there are more instrumental reasons for the public to reject military ventures likely to result in many civilian casualties. Disregard for civilian lives tends both to weaken international backing for military action and to accentuate grievances in the target state (Condra and Shapiro 2012), in both cases making the war harder to win. Meanwhile, in ongoing conflicts, the public may read extensive civilian casualties - as it does military casualties (Gartner and Segura 1998) - as a signal that things are not going according to plan, which in turn will erode approval of action. This would be true almost by definition in a context in which the central motivation for action in the first place was to alleviate civilian suffering. Boettcher (2004) shows that the number of civilians under threat in humanitarian crises did have a weak positive impact on American (students') willingness to intervene militarily on their behalf, from which we can infer at least some concern for civilians in support-for-war judgments. 
Existing evidence provides limited basis for judging whether civilian casualties do indeed influence public support for war. One approach is to gauge the apparent impact on poll trends of the occasional cases in which large-scale civilian casualties are brought to the public's attention. The evidence here is mixed. One vivid null finding is from the Amiriyah bunker incident during the 1991 Gulf War. The US air force was clearly implicated in an attack on a civil defense bunker - also claimed to be a command-and-control facility for the Iraqi army - that left several hundred civilians (including many children) dead. Although the attack was widely reported in the US media (with one poll showing $92 \%$ of American citizens to have been aware of the incident), polls showed no sign of a dent in the strong public support for the military action (Larson and Savych 2006, 43). On the other hand, there is evidence that reports of civilian harm in Abu Ghraib prison led to a statistically significant fall in support for the Iraq War and approval of George W. Bush's handling of it (Voeten and Brewer 2006).

Of course, it remains hard to pick out an effect of civilian casualties given the multiple other forces acting on such trends in approval for war. A different approach is taken by Eichenberg $(2005,172)$, whose collation of polling data indicates that mentioning civilian casualties in a question stem reduces support for war by about ten percentage points. Attacking the same research question experimentally, Gelpi et al. (2009, 256-7) recorded a 17-point difference between the 'treatment' question - asking about approval of a hypothetical military action "if it resulted in 2,000 civilian deaths" - and a control question with no such clause. Yet there is a basic problem with this kind of evidence: the blatancy of the primes. The susceptibility of survey responses to question wording is very well established and so it is no surprise that mentioning civilian casualties - an argument against military action - explicitly in a question has a marked effect on approval. This is not just a matter of social desirability bias as mentioned earlier; it is also simple cueing, respondents without strong views on military action grasping at the consideration helpfully provided (Zaller and Feldman 1992; Tourangeau et al. 2000). 
If the problem with these questions is that the independent variable pollutes the dependent variable, the reverse problem afflicts the evidence presented by Larson and Savych (2006). In multivariate models of support for various US military actions, they find that reactions to civilian casualties do have significant negative effects. Yet these reactions are elicited via questions - such as "in its efforts to try to avoid civilian casualties in Iraq, do you think that the United States is doing too much, too little or about the right amount?" - which, as the authors acknowledge (e.g. p. 229), are highly likely to be endogenous to prior support for the conflict. In short, the dependent variable pollutes these independent variables. When more neutral questions were asked, such as estimates of civilian casualty numbers or reported concern about civilian casualties, the effects of these on support for war were non-significant.

The problems in making causal inference from these studies can be resolved by experimental methods in which casualty numbers - and other casualty-related information - are manipulated and the effects observed on support for war. This method, commonly used in the military casualties literature (e.g. Boettcher and Cobb 2006; Gelpi et al. 2009, ch. 4; Gartner 2011; Kriner and Shen 2013), has very seldom been used to gauge public reactions to civilian casualties - and never yet on representative samples. The most important exception is the pair of experiments fielded via Mechanical Turk and reported by James Igoe Walsh (2015). This showed clear evidence of civilian casualty aversion, with support for force responsive both to the mention of such casualties and to an estimate of numbers (via a manipulation of the likely proportion of civilians among those killed). Indeed, the prospect of civilian casualties in Walsh's first experiment seems to trump that of military casualties, although the comparison can only be rough because only in the military case was an estimate of numbers provided.

Another study worth noting is Friedrich and Dood's (2009) two experiments gauging casualty tolerance among small samples of US college students. In each case manipulating whether the question concerned US troops or foreign civilians, they first ran a study asking each participant how many more casualties in Iraq he or she would be willing to accept before 
wanting the US to withdraw. The second experiment concerned possible future military action to halt Iran's nuclear enrichment activities, and so participants were asked about 'projected' casualties. This method of measuring casualty aversion has its problems (Gelpi et al. 2009, 8082) and the absolute numbers of casualties mentioned are probably not all that informative. What matters here is the relative point: acceptable death tolls were not significantly higher (and, in the Iran case, were actually rather lower) among participants considering civilian casualties. So, if we can assume that these respondents were averse to military casualties, then they were also averse to civilian casualties.

One main purpose of this article is to test whether representative samples of Western adults show the same concern about civilian deaths. However, the detailed treatment of civilian casualty aversion that has been lacking also requires an examination of the circumstances under which that concern is activated - or mitigated. We consider those circumstances next.

\section{Moderators of civilian casualty aversion}

In identifying likely moderators of public reactions to civilian casualties, it is useful to contrast what might be called utilitarian and social psychological models. The first describes the kind of cost-benefit analysis approach that has become the dominant framework for understanding not only public reactions to military casualties (Larson 1996; Gelpi et al. 2006) but also support for war in general (Jentleson 1992; Aldrich et al. 2006). The latter portrays citizens as more influenced by affective considerations, for example the extent to which casualties are humanized or perceived as 'innocent'. ${ }^{2}$ Friedrich and Dood (2009) help to illustrate the distinction via two

\footnotetext{
${ }^{2}$ This utilitarian/social psychological distinction has something in common with but does not map neatly on to the rationalist vs. elite-driven debate about military casualty sensitivity (e.g. Berinsky and Druckman, 2007; Gelpi and Reifler, 2008). Both utilitarian considerations like the probability of success and affective considerations like the ingroup/outgroup status of civilian
} 
priming conditions used with the economics students in their first experiment. In the introduction to the survey, half of the participants heard themselves characterized "as someone who is receiving formal training in cost-benefit decision-making"; the other half heard a reference to their community service activities and, as such, were primed to think in more humanistic terms.

At the heart of the utilitarian model is the number of civilian casualties. More casualties mean a costlier war and so, with the benefits held constant, should mean reduced public approval. This simple equation contrasts with the detailed debate about the relationship between military casualties and support for war, involving disputes about whether that relationship is linear or loglinear and whether cumulative or marginal casualties matter more (Mueller 1973; Gartner and Segura 2008; Gartner 2008a). While that debate was driven by aggregate time series analysis of casualty rates and opinion poll trends, our study is based on survey experiments allowing only limited manipulation of civilian casualty numbers. As such, we cannot draw precisely the functional form of the relationship between civilian deaths and public support but we can address some basic questions about that association. Most simply, how responsive is support for force to increasing numbers of civilian casualties? Are there signs of numbing, whereby large numbers begin to have diminishing effects because people cannot process the implications of these statistical aggregates (Slovic 2007)? Meanwhile, at the lower end, does responsiveness only begin at a certain point because a certain number of civilian casualties are regarded - consciously or otherwise - as acceptable or inevitable?

Another core term in the utilitarian model is the perceived success of military action. Gelpi et al. conclude that "beliefs about the likelihood of success matter most in determining the public's willingness to tolerate US military deaths in combat" $(2006,8)$. Insofar as citizens also show aversion to foreign civilian casualties, we can expect likelihood of success to have a

casualties can be framed or spun by elites. Our interest remains in the question of which type of consideration does more to inhibit public support for war. 
similar moderating effect. This 'success' could be defined in various ways, both by the elites proclaiming it and by their public audience (Berinsky and Druckman 2007), but the point remains the same. The more convinced is the public that military action will deliver the expected benefits, the readier it is to pay the costs in terms of foreign civilian casualties. Conversely, especially when the anticipated civilian death toll is very high, any skepticism about the success of military action may erode public support for war.

We turn now to the social psychological model, in which a first likely moderator of casualty aversion is the perceived similarity of the foreign civilians under threat (Riek et al. 2006). While their mere foreignness introduces one obvious source of difference, there are also potential sources of similarity and thus ingroup status. Religion is one obvious example, particularly pertinent in a post-9/11 era in which, as Smidt puts it, "militant Islam may well have replaced the Soviet Union in the eyes of most Americans as the object of opposition in American foreign policy" (2005; see also Kalkan et al. 2009). Two recent studies found the US and British publics more willing to use force against Islamic than against Christian countries (Johns and Davies 2012; Lacina and Lee 2012), which at the very least suggests that those publics might be more averse to Christian than to Muslim civilian casualties. ${ }^{3}$ The same pair of studies also highlighted adversary regime type as a factor influencing support for war (see also Tomz and Weeks 2013) and so it is at least worth examining whether the public is also more concerned about civilian deaths in democratic than in autocratic states. On that front, however, there are also grounds for doubt. Regime type is a rather less human or personal basis for ingroup status than is religion. Moreover, civilians in an autocratic state might be regarded as innocent victims

\footnotetext{
${ }^{3}$ This may help to explain why Borrelli and Lockerbie (2008), looking only at polls from the second Gulf war, record just a five-point negative effect of mentioning civilians, compared to the ten points recorded in Eichenberg's (2005) broader analysis. If Iraqi civilians score particularly high on 'other'-ness, this could mitigate public concern about their safety.
} 
of their government's aggressive foreign policies, reducing hostility against them (FalomirPichastor et al. 2011). While not explicitly manipulating regime type, Gelpi et al. compared reactions to North and South Korean civilian casualties and found public support for war to fall by the same margin $(2009,256)$.

Mention of innocence highlights the framing of civilian deaths as another important moderator of casualty aversion. What we refer to here is not the kind of numbers-in-context frame examined by Boettcher and Cobb (2006) and Gartner (2008b) in the case of military casualties - those are more like modifications of the cost-benefit model. Our concern instead is with the way that civilian casualties are described or presented. The phrase civilian casualties is itself rather bowdlerized in two ways: the reference to 'civilians' rather than to 'people' or some other more humanizing term; and, as also with the military, the euphemistic use of 'casualties' rather than deaths. Various alternatives - mentioning deaths more explicitly, describing civilians as 'ordinary people', using an 'innocent bystanders' frame - seem likely to generate more empathy and, in turn, perhaps to erode support for the military action that puts civilians at risk. The striking effect of civilian casualties in Walsh's (2015) experiment may be due at least in part to the cueing word 'innocent' in the treatment.

Another cue for innocence, more indirect but still powerful, is the gender and age of casualties (Carpenter 2006). This could be a matter of framing - that is, simply reminding the public that women and children are likely to be among the casualties - or a case of providing concrete information about actual female or juvenile deaths. In the context of military casualties, Gartner (2008b) finds that the loss of servicewomen does have a disproportionate effect on public opinion but only if what he calls primary casualty information - numbers and trends in overall casualties - is unclear. This implies that a utilitarian model has the potential to trump a social psychological model. It is hard to know whether these findings can be extrapolated to the case of civilian casualties. Nonetheless, since 'women and children' have traditionally been deemed to deserve particular protection from the consequences of war - that is, to be the 
paradigm instances of non-combatant immunity (although see Sjoberg, 2006) - then it seems likely that public support for military action will be inhibited should they be explicitly mentioned as likely civilian casualties.

A final component of the social psychological model is the identifiability of civilian casualties. Studies of the 'identifiable victim' effect (Jenni and Loewenstein 1997; Slovic 2007; Small and Loewenstein 2003) indicate that the key to humanizing casualties is to highlight the plight of particular individuals or families. Such 'exemplars' are a stock means by which the media illustrate statistical arguments (Brosius and Bertholt 1994), and are more likely than is quantitative information to activate affective reasoning (Small et al. 2007). The identifiability of a victim is enhanced by visual information. Gartner (2011) shows that the images accompanying coverage of military casualties can influence support for the conflict, and again there is reason to suppose that the same is true with civilian casualties. Parry (2012) identifies several ways in which photos of casualties may vary, many of which fall under the heading of 'graphicness' (see also Silcock et al. 2008). One such is the degree of physical alteration to the victim: that is, the extent to which injuries are highly visible (Fahmy 2005). The relationship between graphicness and impact is not straightforward, however. While the portrayal of injuries and suffering may help to generate empathy, graphic photographs can also have an anaesthetizing effect (Sontag 2003). A more 'normal' photograph of a foreign civilian while alive and well may do more to encourage humanization.

The utilitarian and social psychological models of civilian casualty aversion are to some extent compatible. Public support for force could respond to all of the factors mentioned above. One way of comparing the two models is simply to assess the relative importance of cost-benefit and more affective considerations. A subtler means is to test for interactions between the two. The social psychological model would predict that responsiveness to casualty numbers depends heavily on how those casualties are seen and felt by the public. If, however, support for war 
dwindles as the civilian death toll rises, regardless of factors like similarity, framing, or identifiability, then that would support the utilitarian model.

\section{Data and experiments}

The empirical basis for this study is a quartet of vignette-based survey experiments (of the kind reported by, for example, Herrmann et al. 1999; Boettcher and Cobb 2006; Walsh 2015). The first two of these were fielded in parallel on American and British samples; the third and fourth are available only in the British survey. ${ }^{4}$

The US data $(\mathrm{N}=2,072$, response rate $67.4 \%)$ were collected in a 2010 survey carried out under the auspices of the Time-Sharing Experiments for the Social Sciences (TESS) project. Fieldwork was conducted over the internet by Knowledge Networks (KN). The KN on-line panel via which TESS surveys are implemented is a probability-based panel, selected using randomdigit dial (RDD) and address-based sampling methods, and is representative of the American adult population. The British data are taken from Waves 1 and 3 of a major study of foreign policy attitudes (Wave 1: $\mathrm{N}=2,628$, response rate 61.5\%; Wave 3: $\mathrm{N}=2,140$, retention rate from Wave 1 of $81.4 \%^{5}$ ). The surveys, like those including the support-for-war experiments reported by Tomz and Weeks (2013), was administered over the internet by YouGov, whose 300,000

\footnotetext{
${ }^{4}$ The US and British data are archived at http://www.tessexperiments.org/data/johns798.html and https://discover.ukdataservice.ac.uk/catalogue/?sn=850860 respectively. Both links lead to further information about sampling, fieldwork, and design. Materials necessary for replicating these analyses are available at [URL TO BE ADDED BY JCR].

${ }^{5}$ The response rates are not strictly comparable. Since members of the KN panel have a known probability of selection, we can calculate a response rate taking into account all sources of nonresponse. With the YouGov opt-in panel, response rates are, in effect, completion rates, representing the proportion of those asked to complete a survey that did so.
} 
panel members formed the sampling frame. Unlike KN, YouGov uses an opt-in panel and thus delivers non-probability samples. These different sampling techniques mean that we cannot simply pool the US and British data or precisely calculate the statistical significance of differences across the two cases. Instead, we run each analysis in parallel, consistent with our goals of broad comparison and cross-validation. ${ }^{6}$

The four vignettes, the manipulations involved, and the dependent variable items are set out in full in the appendix. For swifter cross-referencing, the core details are summarized in Table 1. Three of the four experiments measure public support for air strikes by the US or UK military; the fourth, comparing civilian and military casualties, refers more vaguely to "intervention by British troops". Basing the scenarios on aerial attack reflects the fact that military strategists often choose that option over ground combat to reduce the risk of military casualties, even if this greatly increases the likely civilian death toll (Downes 2008). All four experiments involve manipulations of casualty numbers alongside other contextual factors representing the key moderators highlighted above. We estimate the effects of the experimental manipulations using OLS regression and illustrate the casualty coefficients in effects diagrams. ${ }^{7}$

\footnotetext{
${ }^{6}$ Two more points should be noted about the data sources. First, since the British experiments were embedded into a longer and multi-wave survey, the overall instrument is not the same as that fielded in the US. But in both cases the experiments were randomized in order and separated by buffer items on different topics, helping to minimize context or spillover effects (Transue et al. 2009). Second, the YouGov survey in Britain was fielded a little earlier (Wave 1, 18-19 January; Wave 3, 15-22 February) than the KN survey in the US (16-26 March). Happily for all concerned, no major foreign policy events that might disrupt comparison occurred in the interim. ${ }^{7}$ The use of a GLM technique is vindicated by the fact that responses to our dependent variables closely approximated a normal distribution (with no sparse categories and none having a FisherPearson skewness measure of greater than \pm 0.25 ).
} 
Table 1. Summary of the four experiments

\begin{tabular}{|c|c|c|c|c|c|}
\hline & & Experiment 1 & Experiment 2 & Experiment 3 & Experiment 4 \\
\hline \multicolumn{2}{|l|}{ Context } & Hypothetical ('Country A') & Iran & $\begin{array}{l}\text { 'Middle Eastern } \\
\text { country' }\end{array}$ & Hypothetical ('Country A') \\
\hline \multicolumn{2}{|l|}{ Scenario } & $\begin{array}{l}\text { Air strikes for aggressor } \\
\text { restraint (prospective) }\end{array}$ & $\begin{array}{l}\text { Air strikes on nuclear } \\
\text { facilities } \\
\text { (prospective) }\end{array}$ & $\begin{array}{l}\text { Air strikes on local } \\
\text { regime base } \\
\text { (retrospective) }\end{array}$ & $\begin{array}{l}\text { Intervention by British } \\
\text { troops }\end{array}$ \\
\hline \multirow{9}{*}{$\begin{array}{l}\text { Manipulated } \\
\text { variable }\end{array}$} & Casualty numbers & [no mention] $/ 100 / 3,000$ & $50 / 500 / 5,000 / 50,000$ & $10 / 100$ & \begin{tabular}{|l|}
$5 / 10 / 20 / 50 / 100 / 200 /$ \\
$500 / 1,000 / 2,000 / 5,000$
\end{tabular} \\
\hline & \begin{tabular}{|l|} 
Target state religion \\
\end{tabular} & Christian/Islamic & & & \\
\hline & Target state regime & Democracy/ dictatorship & & & \\
\hline & Casualty framing & & $\begin{array}{l}\text { 'Civilian casualties'/ } \\
\text { 'ordinary people'/'innocent } \\
\text { people'//innocent people, } \\
\text { many of them women and } \\
\text { children'9 }\end{array}$ & & \\
\hline & Likely success & & $\begin{array}{l}\text { Delay nuclear program by } 1 \\
\text { year } / 10 \text { years }\end{array}$ & $\begin{array}{l}\text { Elite cue included/ } \\
\text { omitted }\end{array}$ & \\
\hline & Gender/age & & & $\begin{array}{l}\text { Man (35)/woman (35)/ } \\
\text { boy (2) }\end{array}$ & \\
\hline & Visual frame & & & $\begin{array}{l}\text { No photo]/ healthy } \\
\text { photo/ injured photo }\end{array}$ & \\
\hline & Casualty type & & & & Military/civilian \\
\hline & Purpose of action & & & & $\begin{array}{l}\text { Prevent human rights } \\
\text { abuses/Open up oil } \\
\text { pipelines }\end{array}$ \\
\hline \multicolumn{2}{|c|}{ Dependent variable 1} & 7-pt oppose-support scale & 7-pt oppose-support scale & 7-pt justifiability scale & 7-pt oppose-support scale \\
\hline \multicolumn{2}{|c|}{ Dependent variable 2} & & & 7-pt discomfiture scale & \\
\hline
\end{tabular}




\section{Experiment 1 results}

In Experiment 1, respondents were asked whether they supported air strikes against weapons facilities in a hypothetical state that, according to the US/British government, was planning aggression against neighboring states. Regression results - unstandardized coefficients and robust standard errors - from this experiment are reported in Table 2. ${ }^{8}$ We test first a model with the main effects of casualty numbers (and of the other manipulations), before introducing interactive effects in Model 2. ${ }^{9}$

\footnotetext{
${ }^{8}$ In this and later tables, statistical significance is denoted as follows: $* * *=p<0.01$; $* *=\mathrm{p}<0.05 ; *=\mathrm{p}<0.10$. We highlight results in the latter category because null findings here are substantively important, and we want to emphasize where these are not even borderline significant.

${ }^{9}$ To correct for any differences that survived random assignment, we control in all models for several socio-demographic and attitudinal variables at the individual level: age, sex, religious identification, education, links with the military, party identification, and nationalism (tapped by a Likert item: "Generally speaking, America/Britain is better than other countries). To save space, the effects of these are not reported in the tables here but the full models, along with detailed descriptions of these variables, are available in online appendix A2.
} 
Table 2. Effects of manipulated variables on support for war: Experiment 1

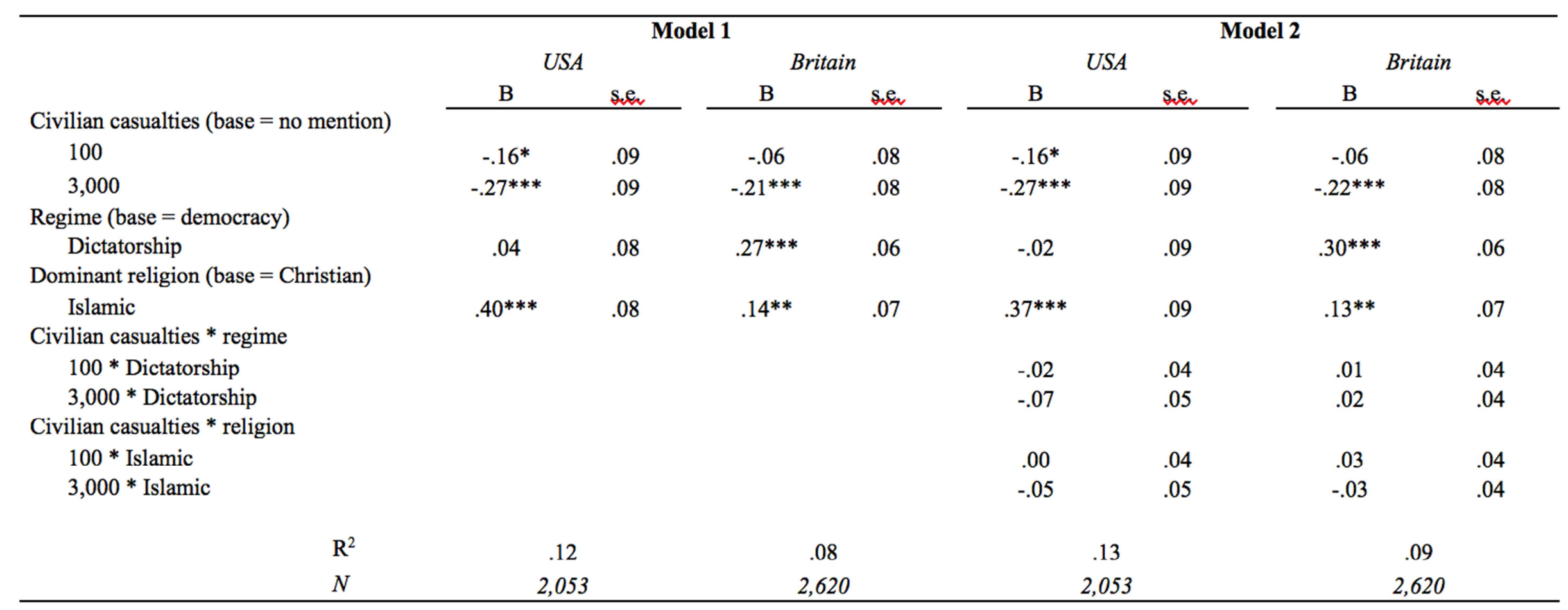


The first point to note is that civilian casualty numbers had a statistically significant if not especially strong effect on both US and British publics. Considering effect size in relative terms, it is instructive to compare with the main effects of the other two manipulations: of regime type and dominant faith. The two publics prioritized these variables very differently the American sample was preoccupied by religion while the British public gave greater weight to regime type - but, in both cases, civilian casualties fell about halfway between the other two variables in terms of effect size. In other words, for both publics, civilian casualties were not a major priority but were not an irrelevant detail.

Figure 1 shows the pattern of civilian casualty effects. This and subsequent such graphs are based on mean predicted values (and 84.3\% confidence intervals around those values ${ }^{10}$ ) estimated from the regression models. Figure 1 confirms that, while the US and British publics differ in their general willingness to support military action, they react fairly similarly to civilian casualties. The discernible difference is that only in Britain is there evidence for our earlier speculation that a certain number of civilian casualties might be taken for granted. Among British respondents, support was not much (and not significantly) weaker in the '100 casualties' condition than in the control condition, whereas the corresponding difference among US respondents was noticeable and significant at least at the $\mathrm{p}<0.10$ level. In neither case, though, is a strong effect achieved simply by priming respondents to consider civilian casualties. The numbers matter, too.

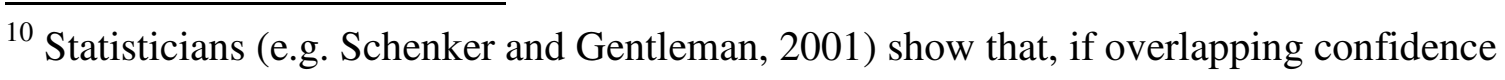
intervals are to be taken as an indication that point estimates are not significantly different, then $95 \%$ intervals make for too conservative a test and $84 \%$ intervals are instead appropriate.
} 


\section{Figure 1. Mean support for air strikes by civilian casualty numbers - Experiment 1}

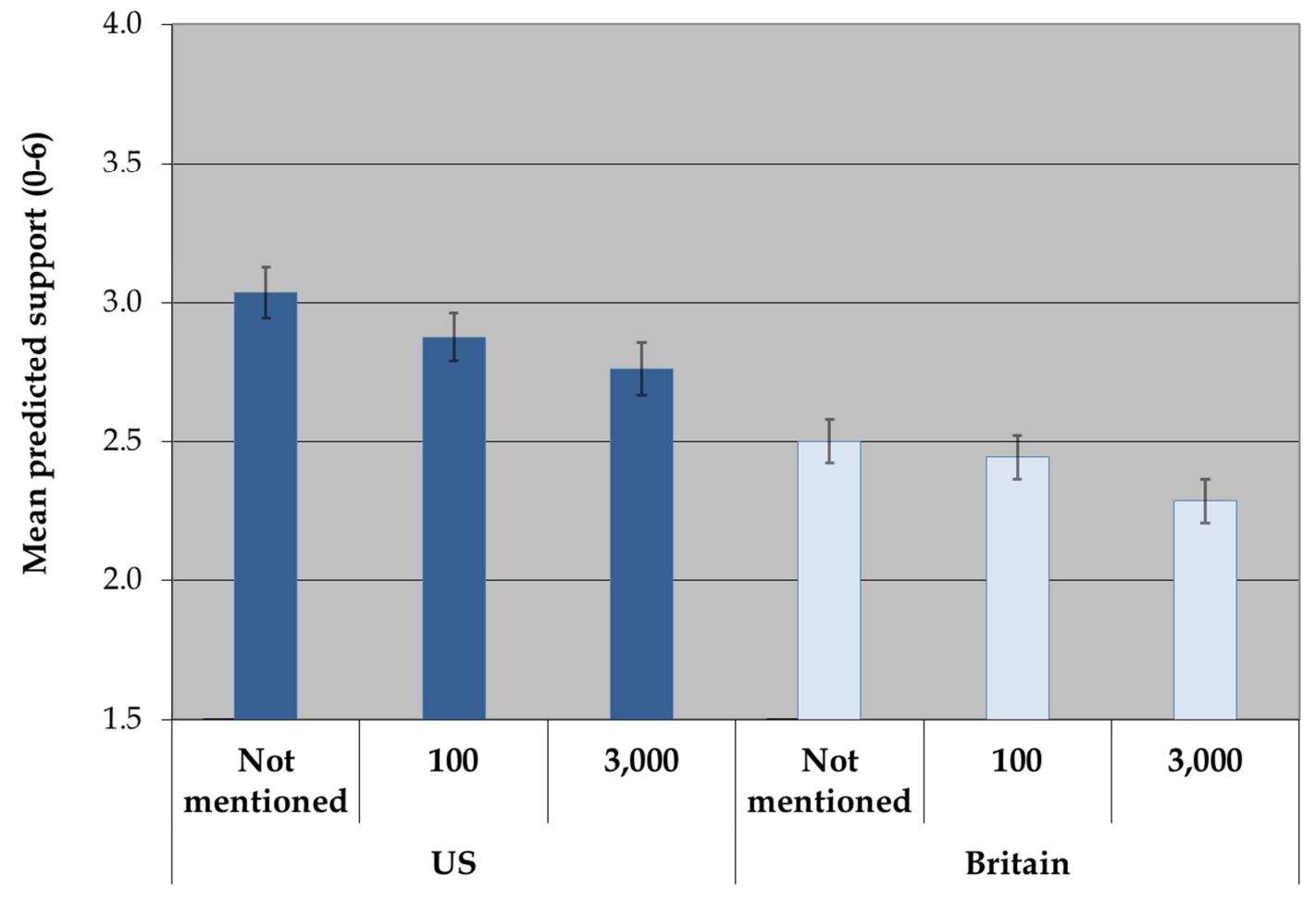

The overall pattern so far, then, is one of similarity across our two cases. And the same is true in Model 2 which includes the interactions between civilian casualty numbers and the characteristics of the target state. All were non-significant in both countries, giving no support to our similarity hypotheses about respondents reacting less strongly to the deaths of Muslim civilians or of those living in non-democracies. (This is not about a lack of statistical power. The interaction coefficients are not consistently positive in the way they would be if the negative effect of casualty numbers was dampened by those casualties being politically or religiously 'other'.) The results from Experiment 1 thus better reflect a utilitarian than a social psychological model of civilian casualty aversion.

\section{Experiment 2 results}

This experiment was based on the possibility of the US and UK governments acting on their longstanding concerns about Iran's nuclear program. In addition to varying the number and 
framing of civilian casualties, we also included a 'success' manipulation, with air strikes estimated to set back the Iranian nuclear program back by ten years or by only one. The results are reported in Table 3. 
Table 3. Effects of manipulated variables on support for war: Experiment 2

\begin{tabular}{|c|c|c|c|c|c|c|c|c|}
\hline & & & & & & & & \\
\hline & $U S A$ & & & & & & & \\
\hline & $\mathrm{B}$ & s.en & $\mathrm{B}$ & s.en & $\mathrm{B}$ & sen & $\mathrm{B}$ & s.en \\
\hline Civilian casualties (base $=50$ ) & & & & & & & & \\
\hline 500 & $-.25^{* *}$ & .11 & $-.20 * *$ & .10 & $-.25^{* *}$ & .11 & $-.20^{* *}$ & .11 \\
\hline 5,000 & $-.27 * *$ & .11 & $-.29 * * *$ & .09 & $-.28 * *$ & .11 & $-.43 * * *$ & .11 \\
\hline 50,000 & $-.37 * * *$ & .11 & $-.52 * * *$ & .09 & $-.36^{* * *}$ & .11 & $-.61^{* * *}$ & .11 \\
\hline Casualty framing (base $=$ 'civilians') & & & & & & & & \\
\hline 'Ordinary people' & .03 & .04 & .02 & .09 & .04 & .08 & -.18 & .16 \\
\hline 'Innocent people' & & & -.09 & .09 & & & -.09 & .09 \\
\hline $\begin{array}{l}\text { 'Innocent people, many woman and children' } \\
\text { Success: delay in Iran's program (base }=1 \text { year) }\end{array}$ & & & -.07 & .09 & & & -.08 & .09 \\
\hline 10 years & $.17 * *$ & .08 & $.27 * * *$ & .07 & .22 & .16 & $.29 * *$ & .13 \\
\hline Civilian casualties * casualty framing & & & & & & & & \\
\hline $500 *$ Ordinary & & & & & -.02 & .06 & -.00 & .06 \\
\hline $5,000 *$ Ordinary & & & & & -.01 & .06 & $-.13 * *$ & .05 \\
\hline $50,000 *$ Ordinary & & & & & .05 & .06 & -.08 & .06 \\
\hline Civilian casualties $*$ delay & & & & & & & & \\
\hline $500 * 10$ years & & & & & .01 & .06 & .03 & .05 \\
\hline $5,000 * 10$ years & & & & & .02 & .06 & .04 & .05 \\
\hline $50,000 * 10$ years & & & & & .02 & .06 & -.04 & .05 \\
\hline $\mathrm{R}^{2}$ & .13 & & & & & & & \\
\hline$N$ & 2,057 & & & & & & & \\
\hline
\end{tabular}


Model 1 shows significant main effects of casualty numbers in both countries. The nature of that effect is illustrated in Figure 2, and it takes a similar and slightly sigmoid form for both publics. Appreciable changes in support come with the move from 50 to 500 casualties, and from 5,000 to 50,000, with the 'curve' flattening out in between. A tentative conclusion is that, at least among those whose judgments are influenced by civilian casualty numbers, there are broadly three levels: (acceptably) low, medium, and (unacceptably) high. Insofar as the British public is somewhat more responsive to casualty numbers, that difference only really emerges at the higher end of this range, US respondents reacting less strongly to the prospect of 50,000 civilian deaths.

Comparisons of effect size are problematic because they depend heavily on the calibration of manipulations. So there is a limit to what we can read into a comparison of the civilian casualty coefficients and the effect of success in Experiment 2. The latter manipulation involved only two conditions and perhaps neither was as extreme as the outermost values of the civilian casualty manipulation. Nonetheless, it is still noteworthy that the casualty numbers effects in both countries look stronger than those of estimated success (as was also the case in Walsh's (2015) M-Turk experiment). After all, the latter variable has featured prominently in research on support for war in general, and on military casualty aversion in particular. Even allowing for differences in the calibration of manipulations, civilian casualty numbers have a clear claim to be considered as one of the variables shaping citizens' judgments about military action. 
Figure 2. Mean support for air strikes by civilian casualty numbers - Experiment 2

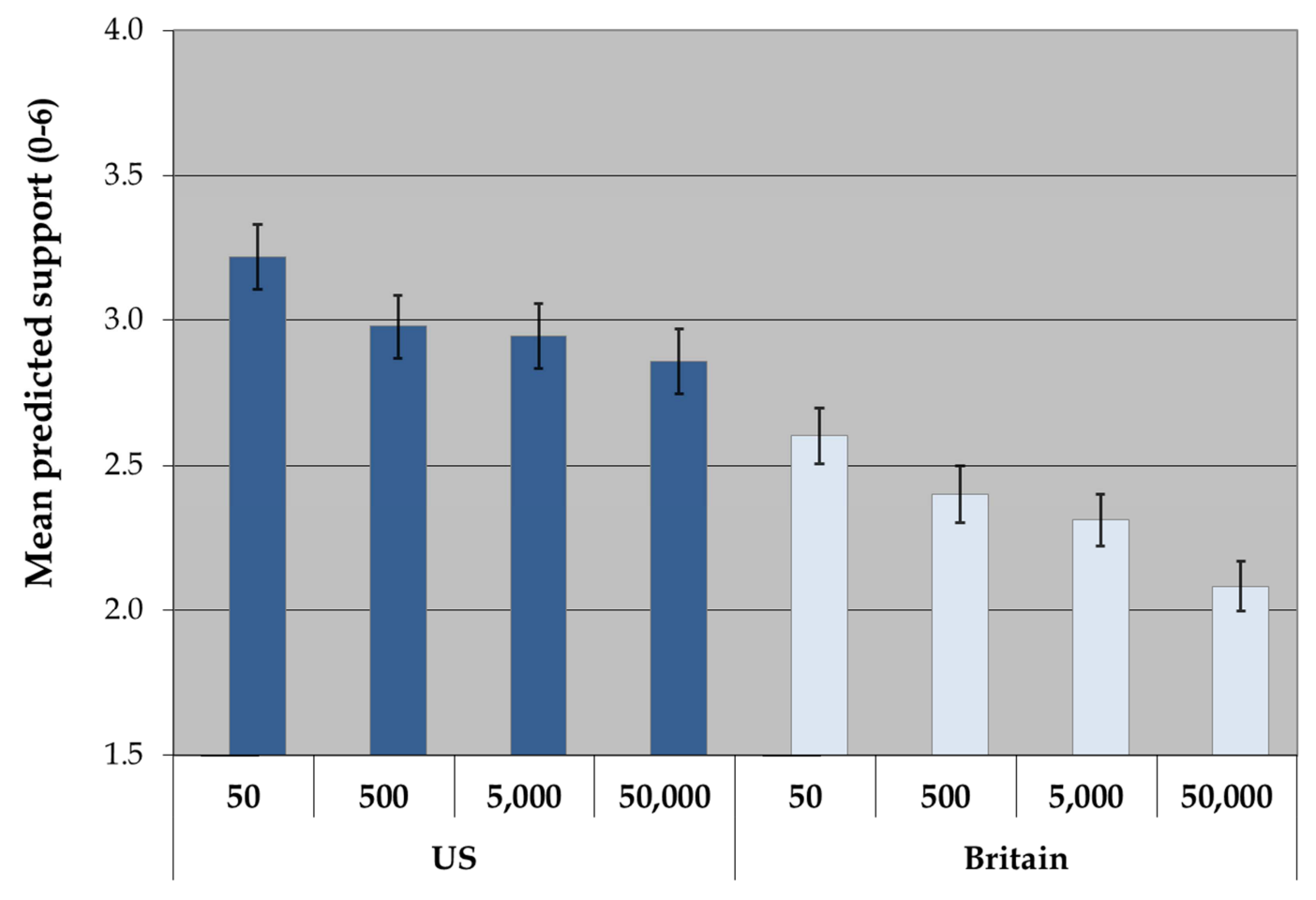

By sharp contrast, the framing manipulation had no significant effect on either public - not even in Britain, where the two main conditions ('civilian casualties' and 'ordinary Iranians') were supplemented by two 'innocence' conditions expressly designed to elicit empathy. Mean support for action was more or less the same regardless of how the expected casualties were described. Considering the supposed potency of the 'women and children' meme in particular, these null findings are startling and entirely contradict our expectations, derived from social psychological theories of empathy and humanization, about casualty framing effects.

This is not to say that the framing of civilian casualties proved wholly irrelevant. In Model 2, there were signs - in Britain, at least - that the use of the phrase 'civilian casualties' has an effect on the way that casualty information is factored into judgments. The negative interactions between the 'ordinary people' frame and the higher casualty numbers indicates that support fell more quickly with the death toll when that description was used. The phrase 
'civilian casualties' does thus seem slightly to de-sensitize respondents contemplating heavy losses. However, since there is no sign of that result in the US data and since, even in Britain, the interactions are weak and inconsistent (and their inclusion results in only a negligible boost to $\mathrm{R}^{2}$ from 0.105 to 0.109 ), we should not get too distracted from the more important findings of Experiment 2, namely that both American and British publics reacted more to casualty numbers than to casualty frames.

On the face of it, that is another triumph for the utilitarian over the social psychological model. However, a qualifier is necessary there. As we noted earlier, one likely feature of a rationalist model is that expected success would moderate civilian casualty aversion. Yet the interaction between numbers and success was more or less non-existent in either country. We do not, for example, observe that citizens tolerate larger numbers of Iranian civilian casualties when the mission is likely to have a substantial impact on the country's nuclear weapons program. This does not invalidate the notion of civilian casualties factoring into a broader cost-benefit calculus, but it does suggest that they are a rather inflexible element in it. Those who react against civilian casualties cannot easily be assuaged.

\section{Experiment 3 results}

One reason why Experiment 2 yielded minimal framing effects might be that the verbal frames used were simply not strong enough. The humanizing effects of narratives, visual cues, and above all identifiability are likely to be more powerful than a summary phrase. Testing this conjecture is the purpose of Experiment 3. That experiment is based on a vignette presented in the form of a newspaper report. The story concerns a British air strike in "a Middle Eastern country" which, while aimed at a power base of the hostile regime, also results in civilian deaths. One version of this report is shown - using the same newspaper format in which it was presented to respondents - in the appendix. The key feature of the 
report is that, in addition to manipulated information on civilian casualty numbers (10 or 100) and military elite claims of success, there is also a brief humanizing narrative about one of the civilians who died - either a 35-year-old woman, a 35-year-old man or a 2-year-old child.

This narrative is accompanied - except in the text-only control condition - by a photograph of that civilian. A further manipulation concerned whether that photograph captured the civilian prior to the attack or while lying injured. ${ }^{11}$

The two dependent variables in Experiment 3 allow us to distinguish different public reactions to the casualty manipulations. Respondents were asked about how far they felt that the air strike was justifiable and how far it made them feel uncomfortable. (The two variables are correlated at only -0.30 , confirming that they measure distinct responses to the vignette.) Each dependent variable is modelled in turn and the results are in Table $4 .^{12}$

${ }^{11}$ Conclusions about casualty age or sex are inevitably contingent on the photographs used. We could not ensure that the photographs were of people at precisely the age mentioned in the story, but hope to have been close enough; we also restated the casualty's age below the photograph in order to keep this at the forefront of respondents' minds. A broader issue is that it may be, for example, that respondents react in that way not to 35-year-old women in general, but to that particular 35-year-old woman. This problem is mitigated by having a set of conditions without photographs, in which age and sex can be varied and everything else held constant.

${ }^{12}$ Since the casualty type and photo manipulations concern an individual rather than the casualties in general, we do not test interactions between these and overall casualty numbers. 
Table 4. Casualty effects in Experiment 3 regressions: a) justifiability of and b) discomfiture with British air strike

\begin{tabular}{|c|c|c|c|c|}
\hline & $\begin{array}{r}\text { Mod } \\
\text { Justifi }\end{array}$ & & $\begin{array}{r}M c \\
\text { Disc }\end{array}$ & \\
\hline & B & s.e. & B & s.e. \\
\hline Civilian casualti & & & & \\
\hline 100 & $-.33 * * *$ & .07 & $.07 * *$ & .08 \\
\hline Exemplar casual & & & & \\
\hline Woman, 35 & -.11 & .09 & $.26 * * *$ & .10 \\
\hline Child, 2 & -.03 & .09 & .13 & .10 \\
\hline Exemplar casual & & & & \\
\hline Healthy & .02 & .09 & $-.20 * *$ & .10 \\
\hline Injured & .03 & .09 & -.02 & .10 \\
\hline & & & & \\
\hline & & & & 10 \\
\hline
\end{tabular}

Displaying the models side by side highlights the contrasting patterns of results. The number of casualties had a moderate effect - comparable in size to those in the previous experiments - on perceived justifiability, but did not significantly influence emotional reactions to the air strike. The reverse was true of the other two casualty manipulations, the age/gender and visual framing of the identifiable victim: they did not affect justifiability but had at least some effect on how comfortable respondents felt about this military action. This pattern goes some way to explaining the dominance of casualty numbers over the other manipulations in Experiments 1 and (especially) 2. As the social psychological model would predict, the framing of civilian deaths does shape public reactions to those casualties, but those affective reactions are not powerful drivers of support for military action.

Figures 3(a) and 3(b), reporting the justifiability and discomfiture models respectively, confirm that the casualty effects are broadly in the expected direction but with notable exceptions. Larger death tolls did seem marginally to increase discomfiture as well as to undermine the justification of the air strikes, but the former effect was not even borderline significant. Both graphs show the same pattern of reactions to casualty type - 'women first, 
then children, and then men' - but the differences were negligible in the justifiability analysis. Visualization, irrelevant for assessments of justifiability, also did surprisingly little to generate negative affect. We expected respondents seeing photos to score higher on the 'uncomfortable' dependent variable than those in the 'no visuals' control condition. In fact, the least discomfiture was reported by those seeing photographs of an 'ordinary', healthy civilian. The difference between the two photo conditions suggests that sympathy rather than humanization is driving any extra discomfiture. But it is not a large difference (with confidence intervals almost overlapping). Once again, then, framing effects were relatively weak - even on a dependent variable designed expressly to tap them. 
Figure 3. Effects of casualty manipulations on evaluations of the British air strike

a) justifiability

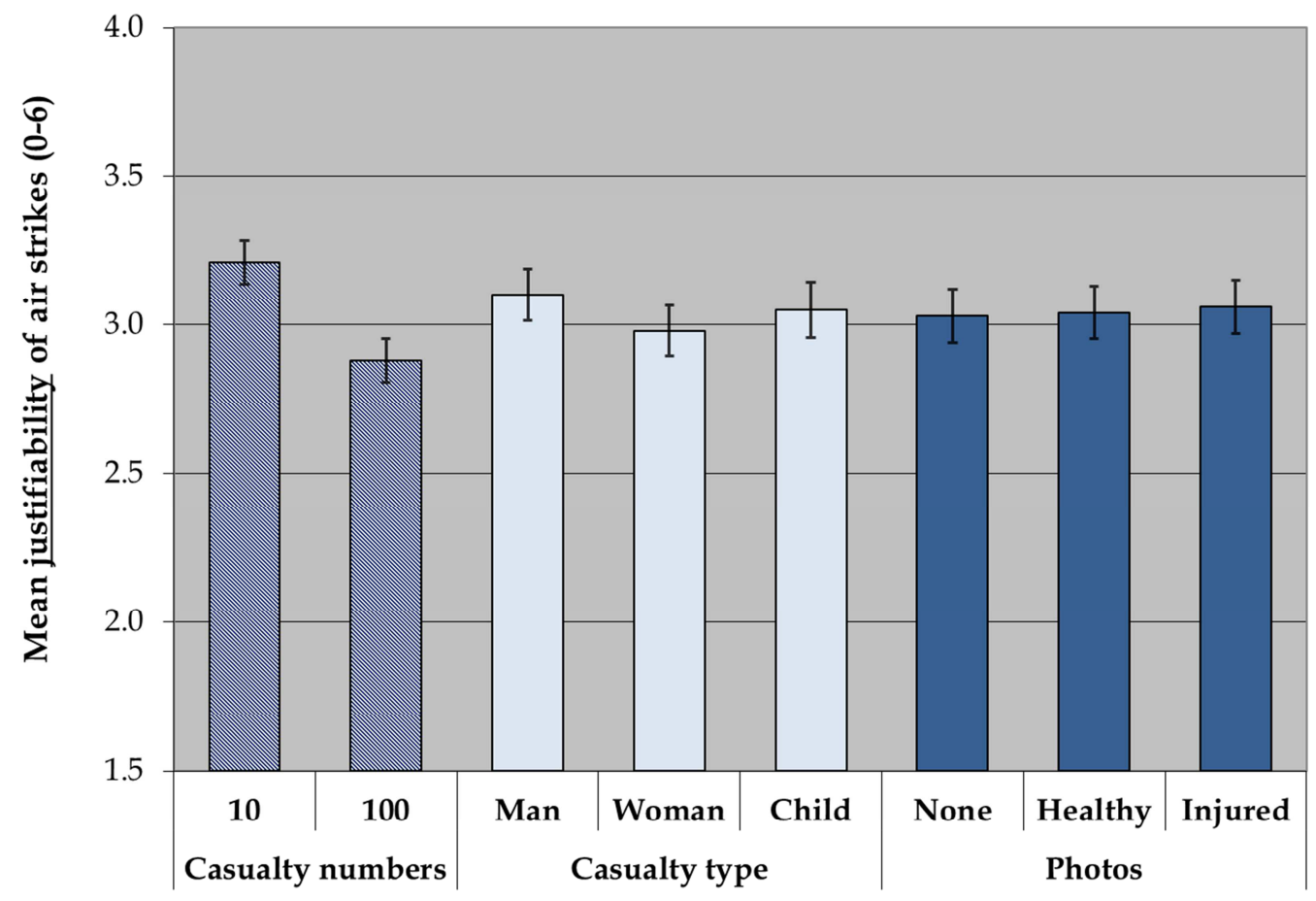

b) discomfiture

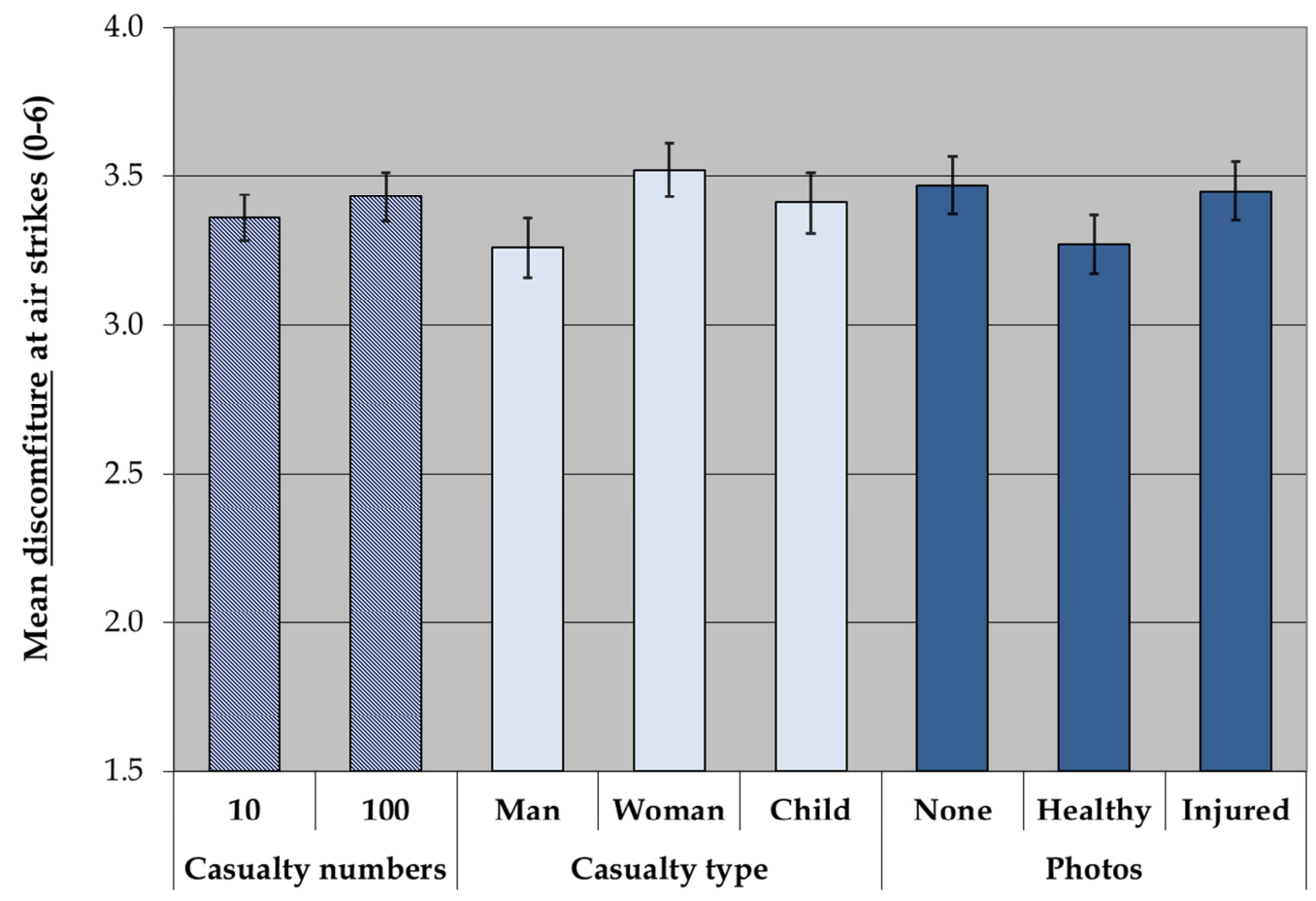




\section{Experiment 4 results}

Given the wealth of evidence that military casualties erode public support for war, our analyses so far have effectively been assessing whether civilian casualties matter as well. What we have not tested yet is whether they matter as much as military deaths. Again, survey evidence is suggestive rather than conclusive. In the survey reported by Gelpi et al. (2009, p. 257), 53\% agreed that "Military planners need to limit the danger to the civilians of the enemy nation during military operations, even if this means exposing U.S. soldiers to greater danger”. A parallel question in the survey from which our British data are taken also elicited a balanced response: $30 \%$ of respondents supported attacking "mainly from the air to reduce the risk of British military casualties" while $29 \%$ favoured "mainly on the ground to reduce the numbers of ordinary people dying" (with the remaining plurality choosing the midpoint on the scale). However, since the assumption of greater military casualty aversion is built into these questions, all we can confidently take from them is that the American and British publics are not limitlessly willing to sacrifice civilians to protect their service personnel. An experimental approach can gauge relative casualty aversion more directly.

In Experiment 4, then, a short survey vignette about potential British military action included information about Ministry of Defence estimates of the death toll among either "British servicemen and women" or "civilians in Country A". The death toll treatment had ten conditions, ranging from 5 to 5,000. An additional manipulation concerned the reason for taking military action: to prevent human rights abuses or to maintain oil supplies to avoid damage to the British economy. This tests whether civilian casualty aversion is intensified when the protection of civilians themselves is the object of the military exercise. In the regressions reported in Table 5, we treat the ten-category casualty variable as continuous in order drastically to simplify the estimation of the casualty numbers with casualty type 
interactions. Later, we relax that assumption in order to examine the form of the numberssupport relationship.

Table 5. Effects of manipulated variables on support for war: Experiment 4

\begin{tabular}{|c|c|c|}
\hline & B & s.e. \\
\hline Number of casualties (10-point scale) & $-.09 * * *$ & .02 \\
\hline \multicolumn{3}{|l|}{ Casualty type (base $=$ military) } \\
\hline Civilian & -.04 & .15 \\
\hline \multicolumn{3}{|l|}{ Reason for action (base $=$ oil interests) } \\
\hline Humanitarian & $-.22 * *$ & .09 \\
\hline \multicolumn{3}{|l|}{ Number of casualties $*$ casualty type } \\
\hline Number * civilian & $.04 *$ & .02 \\
\hline \multicolumn{3}{|l|}{ Casualty type $*$ reason for action } \\
\hline Civilian * humanitarian & .05 & .13 \\
\hline $\mathrm{R}^{2}$ & & \\
\hline$N$ & & \\
\hline
\end{tabular}

The first two rows of data in the table, showing a relatively strong effect of casualty numbers but no main effect of casualty type, are consistent with a utilitarian calculus in which citizens are responsive primarily to death tolls rather than characteristics of those killed. However, there is a positive interaction between numbers and type which implies that support for war falls more slowly when it is a civilian rather than a military death toll mounting. Since the interaction coefficient of 0.04 is not far short of half the -0.09 main effect of casualty numbers, this looks a substantively significant discounting even if the interaction term itself is only significant at the $\mathrm{p}<0.10$ level.

To graph this interactive pattern, we ran a further regression in which casualty numbers were included as a series of dummy variables. In order to dampen some of the stochastic noise given the small group sizes, we collapse adjacent categories of the casualty numbers manipulation. Figure 4 shows clearly that the public is more responsive to numbers in the context of military casualties. As in the other experiments, civilian casualty estimates of over around 100 begin to erode backing for action but, thereafter, support declines only 
slowly even when some large death tolls are mentioned. By contrast, the support curve with military casualties looks to slope more sharply such that, at those higher death tolls, an appreciable gap by casualty type has opened up. The null main effect of casualty type reflects the fact that there is basically no difference between the two leftmost columns in the chart: mentioning 5-10 military casualties has no more effect than mentioning the same number of civilian deaths. Even with service personnel, then, it seems that a certain (albeit small) number of casualties is seen as a cost worth bearing.

\section{Figure 4. Mean support for action by casualty type and numbers - Experiment 4}

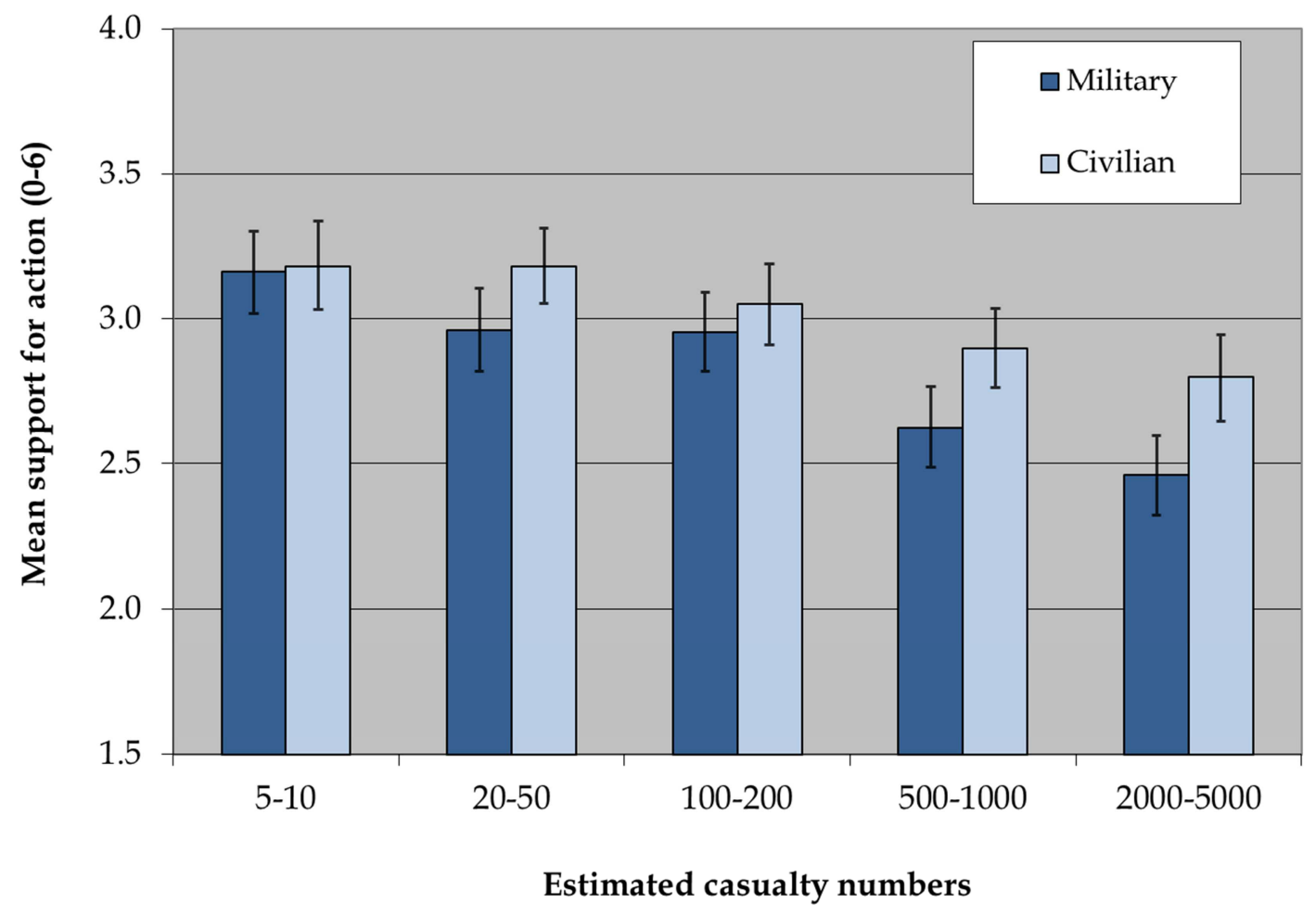

The final result worth noting is the non-significant interaction between casualty type and dispute type. There is no sign that the public is less willing to tolerate civilian casualties during a 'liberal' or humanitarian intervention than during a more 'realist' engagement. This is consistent with our broader theme that casualty reactions fit a cost-benefit better than a social psychological model. There is something utilitarian about a public that gives the same weight to the same number of civilian deaths, regardless of the purpose of fighting. 


\section{Discussion}

The central message of this article is that the public's casualty aversion extends to foreign civilians. Across two Western publics and across multiple experiments with different scenarios, we invariably found support for military action to be lower where the civilian death toll - projected or actual - was higher. The result is robust in another key respect, too, which is that it is strikingly impervious to moderators. We did not find that casualty aversion much weakened when the civilians were from a religious outgroup, or when they were described in a less humanizing manner, or when force was more likely to be successful. Rather, support for war falls as civilian casualties increase, largely regardless of whether other things remain the same. Our four experiments could not of course cover the entire range of potential 'other things'. It might for instance be hypothesized that the prospect of civilian casualties would do less to dampen support if they resulted from military action in which large numbers of the enemy, whether forces or terrorists, were also killed. Pending the test of that hypothesis, however, the evidence so far gives us strong grounds to expect civilian casualty effects to remain.

When drawing conclusions from experimental analyses like this, it is essential to consider the related issues of effect size and external validity. The first point to acknowledge is that the effects of civilian casualties were fairly modest. Even when many thousands of casualties were anticipated, support for war tended to slip rather than to plummet. That said, given the numerous factors that might influence public judgments about military action, it is setting the bar high to expect very large effects from any one factor, and civilian casualty numbers often had an effect comparable to that of other variables - like success, or the nature of the target state - that have been more prominent in previous research. Moreover, while Experiment 4 confirmed that there is greater public aversion to military than to civilian 
casualties, it also confirmed the capacity of large civilian death tolls to erode support. This is obviously important given that, in recent conflicts, the number of civilian casualties has tended to dwarf the number of military casualties. And so, even while there remain reasons to suppose that the public values a (domestic) military over a (foreign) civilian life, there remains the potential for substantial civilian casualty effects on public opinion.

External validity here hinges on how well experiments mimic the way in which the public receives, processes and uses casualty information in the real world. When it comes to civilian casualties, some readers might have an additional issue in mind: is such information made readily available in the real world? To answer 'no' would be to overstate the point, as is confirmed by online appendix A1 (see also Larson and Savych, 2006). Nonetheless, the other point raised by our content analysis is that, even where civilian casualties are mentioned in news coverage, the numbers are often disputed or left unreported. Given that the numbers turned out to be the most potent of our casualty variables, we should acknowledge that there is thus a hypothetical element to our bid for external validity. By incorporating casualty numbers into detailed vignettes and newspaper stories, our aim was to reflect as realistically as possible the way in which civilian casualty information might be presented to and received by the public. As such, we estimated the potential for civilian casualty aversion in the US and British publics, not the actual impact of civilian casualties on public support for any given military action.

For that reason, analyses like ours would be complemented by the kind of time series analysis - tracking civilian casualty rates and support-for-war polls - that has been used to measure that 'actual impact' in the context of military casualties. Null findings would remain partly ambiguous: did the public hear about civilian casualties and ignore the information, or simply not hear about them? Future research along those lines could usefully follow the 
example of Althaus et al. (2014) and incorporate the extent and prominence of civilian casualty reporting as additional independent variables.

Our findings go some way to identifying the basis for civilian casualty aversion. We contend that the dominance of straightforward casualty numbers in public judgments argues for a utilitarian rather than a social psychological model. This is not to say that the perceived costs here are seen somehow in inhuman terms. Our experiments gave us limited opportunity to gauge what respondents saw as the costs of civilian casualties but there is no obvious reason to doubt that casualty aversion was driven by a wish to minimize human suffering and loss of life. Indeed, the failure of social psychological moderators such as group membership and casualty frames only reinforces the idea that the objection to civilian casualties was fundamental rather than circumstantial or conditional.

The unimportance of casualty frames is the aspect of our findings that most surprised us. Perhaps the 'othering' of target populations has been so effective that it is very difficult to trigger public empathy even with deliberately humanizing frames. At the same time, we cannot rule out the possibility that the use of still stronger frames or different photographs would have yielded stronger effects. Still, the consistently weak results across experiments reinforce the general conclusion. So too does the fact that our humanizing narratives were able to influence emotional reactions to the air strike in Experiment 3. These manipulations were not powerless; they just had little influence over approval of military action. This suggests parallel but separate judgment processes: casualty numbers factor into a utilitarian calculus about whether to support military action, while more personalized information about casualties only shapes emotional reactions to such action. Yet such dualism is inconsistent with ample evidence from cognitive psychology - including in the political arena - about the complex interplay between affect and cognition (e.g. Marcus et al. 2000). A more detailed scrutiny of the mechanisms underlying civilian casualty effects is called for. 
We have said relatively little so far about the comparative element of the study, partly because we did not anticipate major differences across our two cases and partly because those expectations were largely borne out. However, there were some differences, notably a generally greater responsiveness to civilian casualties - especially to larger death tolls among the British public. An obvious starting-point in explaining those would be to examine attitudinal differences between the two countries. A person's reaction to civilian casualties will depend not only on aspects of the military context but also her own values and beliefs (see Herrmann et al. 1999). Here, with four experiments and a list of contextual factors to examine, there was no space also to examine the impact of individual-level predispositions. But the question of 'who responds to civilian casualties?' is ripe for future research, not only because it could explain cross-national differences but also because it could usefully supplement our experimental analysis in identifying the causes of civilian casualty aversion. 


\section{References}

Aldrich, John H., Christopher Gelpi, Peter Feaver, Jason Reifler, and Kristin T. Sharp. 2006. "Foreign Policy and the Electoral Connection." Annual Review of Political Science 9: 477-502.

Althaus, Scott L., Nathaniel Swigger, Svitlana Chernykh, David J. Hendry, Sergio C. Wals, and Christopher Tiwald. 2014. "Uplifting Manhood to Wonderful Heights? News Coverage of the Human Costs of Military Conflict from World War I to Gulf War Two." Political Communication 31(2): 193-217.

Berinsky, Adam J., and James N. Druckman. 2007. "Public Opinion Research and Support for the Iraq War." Public Opinion Quarterly 71(1): 126-41.

Boettcher, William A. 2004. "Military intervention decisions regarding humanitarian crises: Framing induced risk behavior." Journal of Conflict Resolution 48(3): 331-55.

Boettcher, William A., and Michael D. Cobb. 2006. "Echoes of Vietnam? Casualty Framing and Public Perceptions of Success and Failure in Iraq." Journal of Conflict Resolution 50(6): 831-54.

Bohrer, Ziv, and Mark Osiel. 2013. "Proportionality in Military Force at War's Multiple Levels: Averting Civilian Casualties vs. Safeguarding Soldiers." Vanderbilt Journal of Transnational Law 46(3): 747-822.

Borrelli, Stephen A., and Brad Lockerbie. 2008. "Framing Effects on Public Opinion during Prewar and Major Combat Phases of the US Wars with Iraq." Social Science Quarterly 89(2): 502-22.

Brandt, Patrick T., Michael Colaresi and John R. Freeman. 2008. "The Dynamics of Reciprocity, Accountability, and Credibility. Journal of Conflict Resolution 52(3): 343-74.

Brosius, Hans-Bernd, and Anke Bathelt. 1994. "The Utility of Exemplars in Persuasive Communications." Communication Research 21(1): 48-78.

Carpenter, R. Charli. 2013. Innocent Women and Children: Gender Norms and the Protection of Civilians. Burlington, VT: Ashgate.

Castano, Emanuele, and Roger Giner-Sorolla. 2006. "Not Quite Human: Infrahumanization in Response to Collective Responsibility for Intergroup Killing." Journal of Personality and Social Psychology 90(5), 804-18.

Condra, Luke N., and Jacob N. Shapiro. 2012. "Who Takes the Blame? The Strategic Effects of Collateral Damage." American Journal of Political Science, 56(1): 167-87.

Downes, Alexander B. 2008. Targeting Civilians in War. Ithaca, NY: Cornell University Press.

Eichenberg, Richard C. 2005. "Victory has Many Friends: U.S. Public Opinion and the Use of Military Force, 1981-2005.” International Security 30(1): 140-77. 
Fahmy, Shahira. 2005. "US Photojournalists' and Photo Editors' Attitudes and Perceptions: Visual Coverage of 9/11 and the Afghan War." Visual Communication Quarterly 12(3), 146-63.

Falomir-Pichastor, Juan M., Andrea Pereira, Christian Staerklé and Fabrizio Butera. 2011. "Do all lives have the same value? Support for international military interventions as a function of political system and public opinion of target states." Group Processes and Intergroup Relations 15(3): 347-62.

Friedrich, James, and Tiffany L. Dood. 2009. "How Many Casualties Are Too Many? Proportional Reasoning in the Valuation of Military and Civilian Lives. Journal of Applied Social Psychology 39(11): 2541-69.

Gartner, Scott Sigmund. 2011. "On behalf of a grateful nation: Conventionalized images of loss and individual opinion change in war." International Studies Quarterly 55(3): 545-61.

Gartner, Scott Sigmund. 2008a. "The Multiple Effects of Casualties on Public Support for War: An Experimental Approach.” American Political Science Review 102(1): 95-106.

Gartner, Scott Sigmund. 2008b. "Deadly Pictures: An Experimental Analysis of Images of Death and the Casualty-Opinion Nexus." Presented at the annual meeting of the American Political Science Association, Boston, MA.

Gartner, Scott Sigmund, and Gary M. Segura. 1998. "War, Casualties and Public Opinion.” Journal of Conflict Resolution 42(3): 278-300.

Gelpi, Christopher, Peter D. Feaver, and Jason Reifler. 2009. Paying the Human Costs of War: American Public Opinion and Casualties in Military Conflicts. Princeton, NJ: Princeton University Press.

Gelpi, Christopher, Peter D. Feaver, and Jason Reifler. 2006. "Success Matters: Casualty Sensitivity and the War in Iraq." International Security 30(3): 7-46.

Gelpi, Christopher and Jason Reifler. 2008. "Success Still Matters: A Response to Berinsky and Druckman." Public Opinion Quarterly 72(1): 125-33.

Haslam, Nicholas, Stephen Loughnan, Yoshihisa Kashima, and Paul Bain. 2008. Attributing and denying humanness to others. European Review of Social Psychology 19(1): 55-85.

Herrmann, Richard K., Philip E. Tetlock, and Penny S. Visser. 1999. "Mass Public Decisions to Go to War: A Cognitive-Interactionist Framework." American Political Science Review 93(3): 553-73.

Jenni, Karen E. and George F. Loewenstein. 1997. "Explaining the "Identifiable Victim Effect." Journal of Risk and Uncertainty 14(3): 235-57.

Jentleson, Bruce W. 1992. "The Pretty Prudent Public: Post Post-Vietnam American Opinion on the Use of Military Force." International Studies Quarterly 36(1): 49-73.

Johns, Robert and Graeme Davies. 2012. "Democratic Peace or Clash of Civilizations? Target States and Support for War in Britain and the US.” Journal of Politics 74(4): 1038-52. 
Kalkan, Kerem, Geoffrey Layman, and Eric M. Uslaner. 2009. “'Bands of Others?' Attitudes toward Muslims in Contemporary American Society.” Journal of Politics 71(3): 1-16.

Key, V. O., 1966. The Responsible Electorate. New York: Vintage Books.

Kriner, Douglas L. and Francis X. Shen. 2013. "Reassessing American Casualty Sensitivity: The Mediating Influence of Inequality. Journal of Conflict Resolution 58(7): 1174-1201.

Lacina, Bethany and Charlotte Lee. 2013. "Culture Clash or Democratic Peace? Results of a Survey Experiment on the Effect of Religious Culture and Regime Type on Foreign Policy Opinion Formation." Foreign Policy Analysis 9(2): 143-70.

Landay, Jonathan, Phil Stewart and Warren Strobel. 2015. "Reports of civilian casualties dim chance of US-Russia alliance in Syria." Reuters, November 25, http://www.reuters.com/article/us-mideast-crisis-usa-russia-idUSKBNOTE0E620151125 (accessed December 30, 2015).

Larson, Eric V. 1996. Casualties and Consensus: The Historical Role of Casualties in Domestic Support for U.S. Military Operations. Santa Monica, CA: RAND.

Larson, Eric, and Bogdan Savych. 2006. Misfortunes of War: Press and Public Reactions to Civilian Deaths in Wartime. Santa Monica, CA: Rand.

Marcus, George E., W. Russell Neuman, and Michael MacKuen, 2000. Affective Intelligence and Political Judgment. Chicago: University of Chicago Press.

Mueller, John E. 1973. War, Presidents and Public Opinion. New York: Wiley.

Parry, Katy. 2011. "Images of liberation? Visual framing, humanitarianism and British press photography during the 2003 Iraq invasion." Media, Culture and Society, 33(8): 11851201.

Pew Research. 2013. "Continued support for U.S. drone strikes." US Politics, February 11, http://www.people-press.org/2013/02/11/continued-support-for-u-s-drone-strikes/ (accessed December 30, 2015).

Riek, Blake M., Eric W. Mania, and Samuel L. Gaertner. 2006. "Intergroup Threat and Outgroup Attitudes.” Personality and Social Psychology Review 10(4): 336-53.

Rothbart, Daniel, and Karina Korostelina (eds.). 2006. Identity, Morality and Threat. Plymouth, UK: Lexington Books.

Schenker, Nathaniel, and Jane F. Gentleman. 2001. "On judging the significance of differences by examining the overlap between confidence intervals." The American Statistician 55(3): 182-86.

Shaw, Martin. 2002. "Risk-transfer militarism, small massacres and the historic legitimacy of war.” International Relations 16(3): 343-60.

Silcock, B. William, Carol Schwable and Susan Keith. 2008. "'Secret' casualties: Images of injury and death in the Iraq War across media platforms." Journal of Mass Media Ethics 23(1): 36-50. 
Sjoberg, Laura. 2006. "Gendered realities of the immunity principle: Why gender analysis needs feminism”. International Studies Quarterly, 50(4): 889-910.

Slovic, Paul. 2007. "If I Look at the Mass, I Will Never Act': Psychic Numbing and Genocide." Judgment and Decision Making 2(1): 79-95.

Small, Deborah A., and George Loewenstein. 2003. "Helping the victim or helping a victim: Altruism and identifiability." Journal of Risk and Uncertainty 26(1): 5-16.

Small, Deborah A., George Loewenstein and Paul Slovic. 2007. "Sympathy and callousness: The impact of deliberative thought on donations to identifiable and statistical victims." Organizational Behavior and Human Decision Processes 102(2): 143-53.

Smidt, Corwin. 2005. "Religion and American Attitudes towards Islam and an Invasion of Iraq." Sociology of Religion 66(3): 243-61.

Sontag, Susan. 2003. Regarding the Pain of Others. London: Penguin.

Tomz, Michael and Jessica Weeks. 2013. "Public Opinion and the Democratic Peace." American Political Science Review 107(4): 849-65.

Tourangeau, Roger, Lance J. Rips and Kenneth A. Rasinski. 2000. The Psychology of Survey Response. Cambridge: Cambridge University Press.

Transue, John E., Daniel J. Lee, and John H. Aldrich. 2009. "Treatment spillover effects across survey experiments." Political Analysis 17(2): 143-61.

Voeten, Erik, and Paul R. Brewer. 2006. "Public Opinion, the War in Iraq and Presidential Accountability." Journal of Conflict Resolution 50(6): 809-30.

Wafa, Abdul, and John F. Burns. 2008. "US Airstrike Reported to Hit Afghan Wedding." New York Times, 5 November, http://www.nytimes.com/2008/11/06/world/asia/06afghan.html?_r=0 (accessed December $30,2015)$.

Walsh, James Igoe. 2015. "Precision Weapons, Civilian Casualties, and Support for the Use of Force." Political Psychology, 36(5): 507-23.

Wright, Oliver. 2015. "Syria air strikes: Cameron said there have been no reports of Iraqi civilian causalities. He's distorting the truth." Independent, December 2, http://www.independent.co.uk/news/uk/politics/syria-strikes-cameron-claims-there-havebeen-no-reports-of-civilian-casualties-in-iraq-since-british-a6757351.html (accessed December 30, 2015).

Zaller, John and Stanley Feldman. 1992. "A simple theory of the survey response: Answering questions versus revealing preferences." American Journal of Political Science 36(3): 579-616. 


\section{Appendix \\ Experimental treatments in full}

\section{Experiment 1}

This question is about a situation in which the US might take military action. Please read the following description of that situation and then answer the question below.

Today the American government has presented evidence to the United Nations that Country A has been developing a secret nuclear weapons program which it intends to use against its neighbors in the region. The government is making the case for air strikes against factories associated with this programme. Professor Andrew Lincoln, a leading expert on military strategy, has estimated that the planned American air strikes would result in the deaths of around one hundred/three thousand civilians/[entire sentence omitted]. The democratically-elected President/unelected dictator of Country A, a predominantly Christian/Islamic country of around 20 million people, has strenuously denied the American government's allegations.

On a scale from 0 (strongly oppose) to 6 (strongly support), how do you feel about American air strikes in this case?

\section{Experiment 2}

Here is another question is about a situation in which the US might take military action. Please read the following description of that situation and then answer the question below.

Western governments, including the American, have long expressed concerns about Iran's nuclear ambitions. In particular, they claim that Iran has secret facilities that are being used to develop nuclear weapons. Iran has consistently denied that these claims are true but, according to the American government, Iran is not far away from being able to launch a nuclear strike. The US is considering air strikes against the Bushehr nuclear facility, which it says is producing the nuclear materials necessary for Iran's weapons program. Since this facility is in a populated area, air strikes are likely to result in civilian casualties/ordinary Iranians dying/innocent people/innocent people dying, many of them women and children. Professor Anna Knott, an expert on the region, estimates the likely civilian death toll at around 50/500/5,000/50,000 people. She adds that air strikes are likely to slow down Iran's nuclear weapons program by one year/ten years.

On a scale from 0 (strongly oppose) to 6 (strongly support), how do you feel about American air strikes in this case?

$N B$ The latter two conditions of the casualty framing manipulation were included only in the British experiment. When fielded in the UK, Experiments 1 and 2 referred to the British government, British air strikes, and so on. 


\section{Experiment 3}

One version of this story is shown below, using the same newspaper format in which it was presented to respondents.

In recent years, much of Britain's military activity has been in the Middle East. Here is a newspaper story about one recent military operation in a Middle Eastern country. Please read it and then answer the question below.

\section{British air strike hits secret police headquarters - and tower block}

\begin{abstract}
British military leaders ad. mitted today that the recent air strikes on the town of Abadeh, which destroyed the headquarters of the regime's secret police, also resulted in the deaths of 10 innocent civilians. "While it was crucial that we destroyed the enemy's power base in order to achieve our long. term objectives in the region, we profoundly regret that the blast also hit the adjacent tower block". said Lieutenant-Colonel
\end{abstract}

operations in the Abadeh area will continue, targeting suspected rebel bases and training centres.

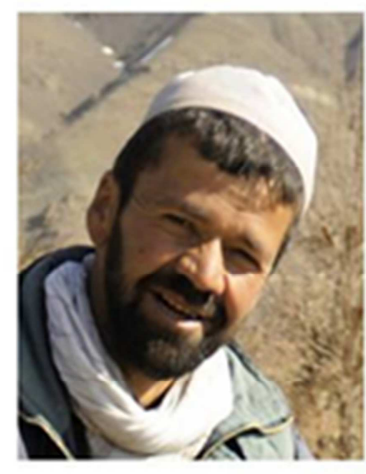

One of the casualties, Behrouz Anfari (35)

Think of a scale from 0 ('totally unjustified') to 6 ('totally justified'). Which number best describes what you think about the British air strikes described in the story above?

This time the scale is a bit different and runs from 0 ('not at all uncomfortable') to 6 ('extremely uncomfortable'). Which number best describes how you feel about the air strikes?

Three elements of the vignette were subject to experimental manipulation as follows:

- Number of casualties: 10; 100

- Type of casualty: 35-year-old man; 35-year-old woman; 2-year-old boy

- Photos of casualty: none; healthy (i.e. pre-strike); injured (i.e. post-strike)

The photographs used are shown overleaf: 


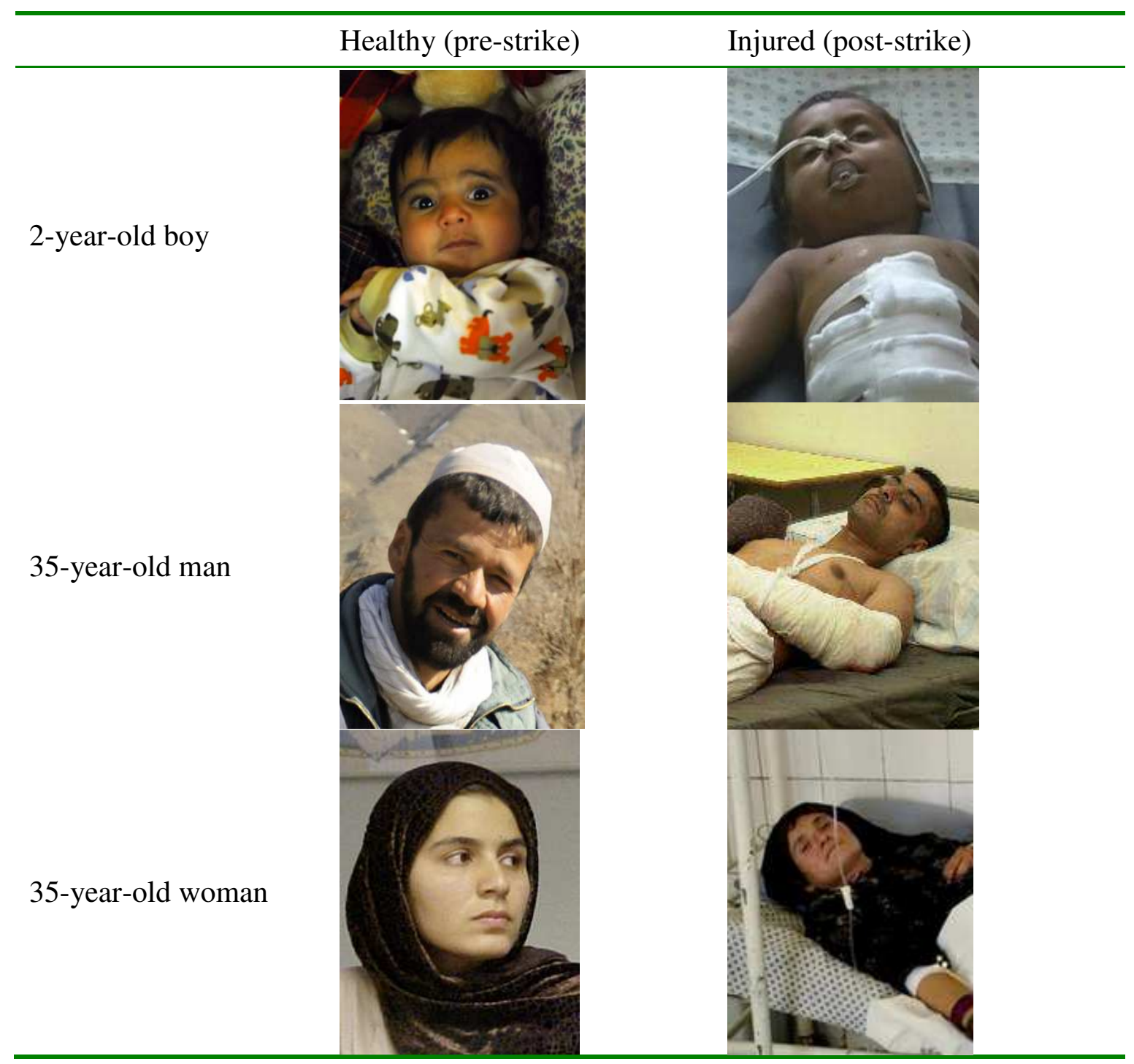

\section{Experiment 4}

The next question is about a situation in which Britain might be called upon to take military action.

Imagine that the government in Country A is involved in widespread human rights abuses against its own people. Intervention by British troops could help to end many of the worst abuses/is threatening a major disruption of world oil supplies which will seriously damage Britain's economy. Intervention by British troops could open up access to the blocked oil pipelines. However, the Ministry of Defence estimates that the required military action is likely to result in the deaths of around 5/10/20/50/100/200/500/1,000/2,000/5,000 British servicemen and women/civilians in Country A. Professor Philip Tyler, a leading expert on Country A, warns that, with tensions in the region very high, Britain must decide very soon about whether or not to take action.

On a scale from 0 (strongly oppose) to 6 (strongly support), how do you feel about British military intervention in this case? 